\title{
Calix[4]arene Schiff bases-potential ligands for fluorescent studies
}

\author{
Mary F. Mahon $^{a}$, John McGinley ${ }^{\mathrm{b}, *}$, A. Denise Rooney ${ }^{\mathrm{b}}$, John M.D. Walsh ${ }^{\mathrm{b}}$ \\ ${ }^{a}$ X-ray Crystallographic Unit, Department of Chemistry, University of Bath, Bath BA2 7AY, United Kingdom \\ ${ }^{\mathrm{b}}$ Chemistry Department, National University of Ireland Maynooth, Maynooth, Co. Kildare, Ireland
}

\section{A R T I C L E I N F O}

\section{Article history:}

Received 30 June 2008

Received in revised form 11 September

2008

Accepted 25 September 2008

Available online 8 October 2008

\section{Keywords:}

Calix[4]arene

Schiff bases

$\mathrm{X}$-ray structure

NMR spectroscopy

Inclusion

Synthesis

\begin{abstract}
A B S T R A C T
A series of novel double-armed calix[4]arene derivatives incorporating imine substituents were synthesised from the Schiff-base reaction of 25,27-bis[2-[(1-formyl-2-phenyl)oxy]ethyl]-p-tert-butylcalix[4]arene (1) with the appropriate amine or hydrazone. All compounds were characterised by various spectroscopic and analytical techniques, and in three cases, by X-ray crystallographic studies. In the case of compound 2, inclusion compounds were synthesised with both $m$-xylene and dimethylformamide and their X-ray structures revealed these inclusion sites - between the pendant arms and in the upper cavity, respectively. In all cases, the pendant arms are bent away from each rather than adopting a face-to-face conformation.
\end{abstract}

(c) 2008 Elsevier Ltd. All rights reserved.

\section{Introduction}

Calix[4]arenes, containing three-dimensional cavities, are popular building blocks in supramolecular chemistry, especially in molecular recognition. ${ }^{1}$ Their controlled synthetic functionalisation allows the use of these compounds in supramolecular chemistry as molecular scaffolds for the construction of various receptors. Modified calix[4]arene derivatives, having additional binding sites at the lower rim, enhance the binding ability of the parent calix [4]arene. They are frequently employed as platforms that permit functional groups to be orientated to provide well-organised cavities. Their development as a force within supramolecular chemistry has resulted from their synthetic availability and their relative ease of modification, coupled with the presence of various cavities, which are capable of binding cationic, anionic or neutral species, which becomes apparent from the number of review articles and books available. ${ }^{1}$

Recently, a number of papers have appeared in the literature concerned with the synthesis and characterisation of Schiff-base derivatives of calix[4]arenes and their application in either photochromic studies or as ion-selective extractants. ${ }^{2}$ Schiff bases offer potential as optical switches resulting from their intramolecular hydrogen transfer ability from the hydroxyl oxygen to the imine nitrogen, in both solution and solid state. ${ }^{2 \mathrm{~b}, 3}$ They have been

\footnotetext{
* Corresponding author. Tel.: +353 1708 4615; fax: +353 17083815 .

E-mail address: john.mcginley@nuim.ie (J. McGinley).
}

incorporated onto both the upper and the lower rims of calix[4]arenes and their ability to complex transition metals assessed. ${ }^{2 a, c, 4}$

As part of a broad study of the interactions of various functional groups at both the wide and the narrow rims, we have prepared and characterised various calix[4]arene derivatives and their metal complexes. ${ }^{5}$ Part of our current investigations into calix[4]arene compounds involves the investigation of their potential use as fluorescent sensors. As a part of that study, this paper describes the calix[4]arene lower rim functionalisation with a variety of Schiffbase ligands (Scheme 1), their syntheses and characterisation and a discussion of their subsequent structures. Our goal is to study the binding properties of transition metal ions with these Schiff-base calix[4]arene compounds and to investigate any interesting properties resulting from these complexation reactions. The comparison of any X-ray crystal structures of metal complexes of the pendant Schiff-base calix[4]arenes with the X-ray structures of the calix[4]arene derivates described in this paper will be very informative. Binding studies on metal complexes will be reported in due course. ${ }^{6}$

\section{Results and discussion}

\subsection{Synthesis}

The synthesis of the starting calix[4]arene, p-tertbutylcalix[4]arene aldehyde $\mathbf{1}$, was carried out according to the reported literature procedure, ${ }^{7}$ involving the reaction of 

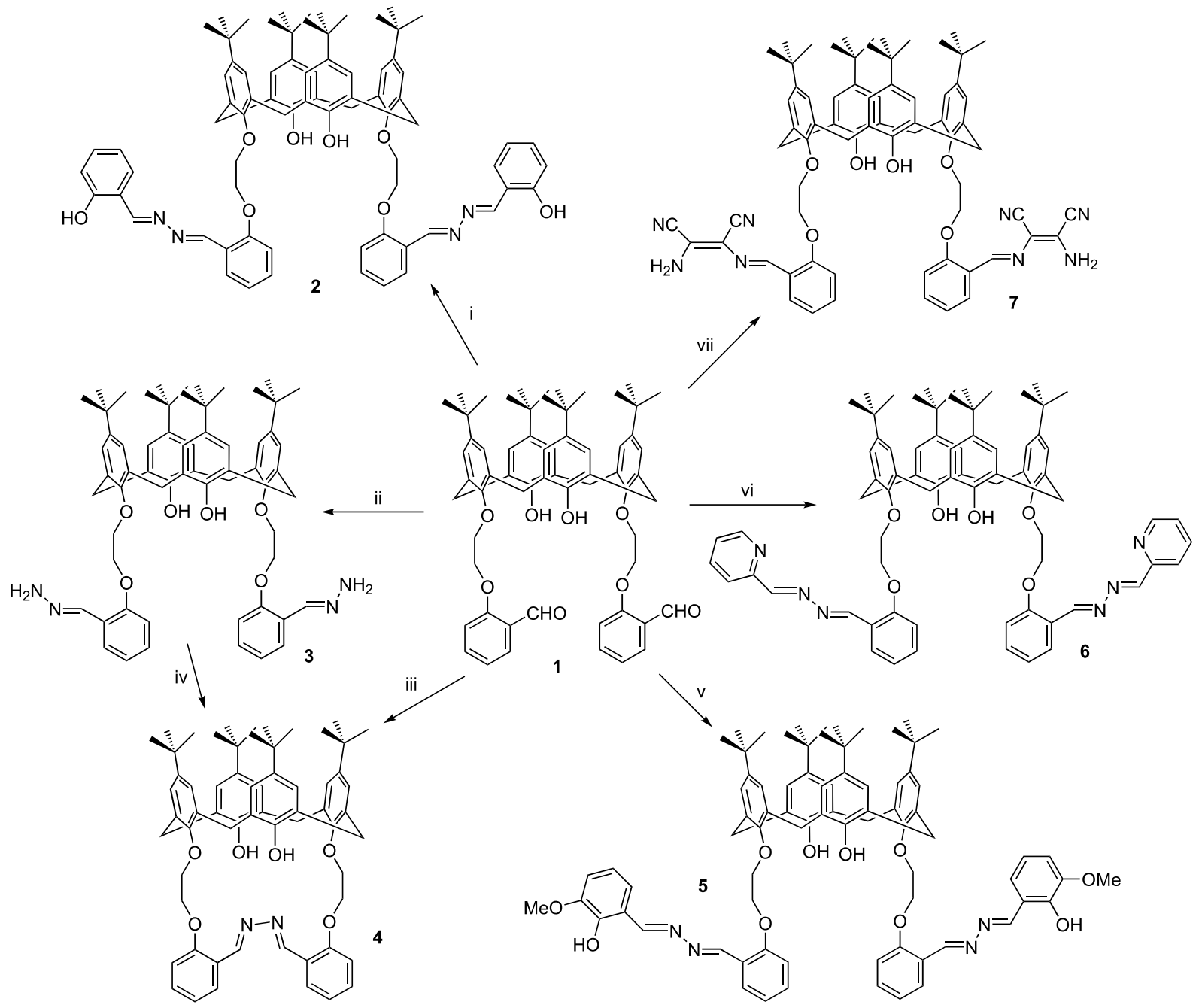

Scheme 1. Reaction conditions: (i) salicylaldehyde hydrazone, acetic acid, abs ethanol, rt, $24 \mathrm{~h}$; (ii) hydrazine hydrate, acetonitrile, rt, $12 \mathrm{~h}$; (iii) hydrazine hydrate, ethanol, $\Delta, 2 \frac{1}{2} \mathrm{~h}$; (iv) ethanol, $\Delta, 24 \mathrm{~h}$; (v) 0 -vanillin hydrazone, abs ethanol, $\Delta, 1 \mathrm{~h}$; (vi) 2-pyridine hydrazone, ethanol, rt, $96 \mathrm{~h}$; (vii) diaminomaleonitrile, acetic acid, abs ethanol, rt, $24 \mathrm{~h}$.

2-(2'-bromoethoxy)benzaldehyde with p-tert-butylcalix[4]arene. Compounds $o$-vanillin hydrazone ${ }^{8}$ and pyridine hydrazone ${ }^{9}$ have been previously reported and were synthesised here using a modified procedure. The Schiff-base reactions of 1 with the various hydrazones or amine compounds were carried out at room temperature to give the products shown in Scheme 1 in high yield. When a reaction mixture was heated, as in the case of 3 going to 4 , we found that the cyclic system was obtained. This intramolecular reaction occurred, presumably, because of the presence of water in our solvent system, thereby causing one pendant imine to decompose to the original aldehyde, which would subsequently react with the remaining amine to give the cyclic system, as shown in 4 . We have previously observed this type of behaviour involving amide bonds rather than amine bonds, ${ }^{5 \mathrm{~b}, 10}$ while other groups have observed similar reactions with other Schiff-base compounds. ${ }^{11}$ All the compounds were characterised by $\mathrm{CHN}$ analyses and by ${ }^{1} \mathrm{H}$ and ${ }^{13} \mathrm{C}$ NMR spectroscopy.

\subsection{NMR data}

The structures of 1-7 were fully characterised using ${ }^{1} \mathrm{H}$ and ${ }^{13} \mathrm{C}$ NMR spectroscopy. Table 1 shows the ${ }^{1} \mathrm{H}$ NMR values for the tertbutyl, aromatic protons, bridging methylene proton and chain methylene proton signals for $\mathbf{1 - 7}$ as well as the imine proton signals for 2-7.
The cone conformation for 1-7 was derived from the bridging methylene proton signals. In all cases, a pair of doublets in the ${ }^{1} \mathrm{H}$ NMR spectra were observed between $\delta 3.1$ and 4.4 with $J=12.7-$ $13 \mathrm{~Hz}$. The 1,3-disubstitution of the lower rim was confirmed by the appearance of two singlet resonances for both the aromatic protons of the calix[4]arenes and the methyl protons of the tert-butyl groups, with the actual positions of the signals dependant on the substituent attached. The formation of the imine compounds 2-7 was determined by the loss of the signals due to the aldehyde group of 1 at $\delta 10.50$ in the ${ }^{1} \mathrm{H}$ NMR spectra and at $\delta 190.2$ in the ${ }^{13} \mathrm{C} \mathrm{NMR}$ spectra and the appearance of signals at $\sim \delta 8-9.3$ in the ${ }^{1} \mathrm{H}$ NMR spectra and at $\sim \delta 150-160$ in the ${ }^{13} \mathrm{C}$ NMR spectra, depending on the substituent attached to the imine nitrogen atom. These values

Table 1

${ }^{1} \mathrm{H}$ NMR chemical shifts of calix[4]arenes 1-7 (300 MHz)

\begin{tabular}{|c|c|c|c|c|c|c|c|c|c|c|}
\hline \multirow[t]{2}{*}{ No. } & \multirow[t]{2}{*}{ Solvent } & \multicolumn{3}{|c|}{ Lower rim } & \multicolumn{4}{|c|}{ Calixarene core } & \multicolumn{2}{|c|}{ Upper rim } \\
\hline & & $\mathrm{OCH}_{2}$ & $\mathrm{OH}$ & $-\mathrm{HCN}-$ & $-\mathrm{CH}_{2-}$ & $-\mathrm{CH}_{2-}^{-}$ & $\mathrm{Ar}-\mathrm{H}$ & $\mathrm{Ar}-\mathrm{H}$ & $t-\mathrm{Bu}$ & $t-\mathrm{Bu}$ \\
\hline 1 & $\mathrm{CDCl}_{3}$ & 4.40 & 7.49 & - & 4.30 & 3.31 & 7.00 & 6.88 & 1.25 & 1.02 \\
\hline 2 & $\mathrm{CDCl}_{3}$ & 4.40 & 7.46 & 8.64 & 4.33 & 3.27 & 6.96 & 6.85 & 1.17 & 1.00 \\
\hline 3 & $\mathrm{CDCl}_{3}$ & 4.24 & 7.77 & 8.21 & 4.39 & 3.33 & 7.06 & 6.85 & 1.27 & 1.00 \\
\hline 4 & $\mathrm{CDCl}_{3}$ & 4.45 & 7.28 & 9.02 & 4.31 & 3.11 & 6.94 & 6.78 & 1.23 & 0.92 \\
\hline 5 & $\mathrm{CDCl}_{3}$ & 4.44 & 7.35 & 8.71 & 4.31 & 3.12 & 6.93 & 6.78 & 1.23 & 0.93 \\
\hline 6 & $\mathrm{CDCl}_{3}$ & 4.37 & 7.67 & 8.62 & 4.36 & 3.28 & 6.97 & 6.87 & 1.21 & 1.01 \\
\hline 7 & DMSO- $d_{6}$ & 4.36 & 8.33 & 8.76 & 4.25 & 3.38 & 7.13 & 7.08 & 1.22 & 1.15 \\
\hline
\end{tabular}


compare favourably with those previously reported for other lower rim calix[4] arene Schiff-base compounds. ${ }^{2 \mathrm{c}, \mathrm{d}, 4 \mathrm{~b}-\mathrm{e}, 7,12}$ The unreacted hydroxyl proton signal appears in the ${ }^{1} \mathrm{H}$ NMR spectra of all the compounds as a sharp singlet between $\sim \delta 7.3$ and 7.9 , with the variation in the position being an indication of the strength of the intramolecular hydrogen bond to the oxygen atom of the neighbouring ring of the calix[4]arene. The bridging ethylene protons of the linker chain appear in the ${ }^{1} \mathrm{H}$ NMR spectra of compounds, 1-7, as a multiplet centred at $\sim \delta 4.4$, except in the case of 3 where the multiplet is found at $\delta 4.24$.

The four aromatic proton signals of the phenyl ring appear as multiplets in the ${ }^{1} \mathrm{H}$ NMR spectra of compounds 1-7, some of which are overlapping. In the case of compounds $\mathbf{2}$ and $\mathbf{5}$, it is difficult to distinguish between the two phenyl rings, which are present in the pendant arm attached to the lower rim. However, in the cases of 3 4, 6 and 7, the four signals are easily discernable and differ significantly from the starting calix[4]arene dialdehyde compound $\mathbf{1}$. Again, the position of the four signals was dependant on the substituent attached to the imine nitrogen atom.

The various substituents attached to the imine group are also easily distinguishable in both the ${ }^{1} \mathrm{H}$ and the ${ }^{13} \mathrm{C}$ NMR spectra of compounds 2-7. In 2, the additional imino-phenol group is clearly observed by a second imine singlet at $\delta 8.64$ as well as a broad singlet for the phenolic $\mathrm{OH}$ group at $\delta 11.71$. In 3 , the primary amine appears as a broad singlet at $\delta 4.95$. In $\mathbf{5}$, the imino-o-vanillin group can be seen by the second imine singlet at $\delta 8.71$, a broad singlet for the phenolic $\mathrm{OH}$ group at $\delta 11.57$ and a singlet for the methoxy group at $\delta$ 3.94. The presence of the pyridyl group in $\mathbf{6}$ is clearly observed as a well-defined series of doublets and triplets, as expected for a 2-pyridyl group. ${ }^{5 c, e, 13}$

\subsection{IR data}

The major difference in the IR spectrum of $\mathbf{1}$ compared to those of 2-7 is the presence of an aldehyde peak at $1682 \mathrm{~cm}^{-1}$ in 1 and the absence of this peak in the Schiff-base compounds 2-7. In the case of 7, two bands at 2232 and $2205 \mathrm{~cm}^{-1}$ are observed, which are indicative of the presence of the nitrile groups. The 3200$3600 \mathrm{~cm}^{-1}$ region of the spectra of $1-7$ contains a broad band with a peak at $\sim 3350 \mathrm{~cm}^{-1}$, which is due to the several $\mathrm{OH}$ groups present in all the compounds. In the case of $\mathbf{3}$ and 7, an additional sharp band is observed at 3534 and $3460 \mathrm{~cm}^{-1}$, respectively, which is due to the presence of a free $\mathrm{NH}_{2}$ group in both of these compounds. Because of the complexity of compounds 1-7 and also their resulting IR spectra, it is impossible to assign other bands with confidence.

\subsection{X-ray crystallographic studies}

Table 2 gives the crystal data and refinement parameters for the four structures and Table 3 gives the intramolecular hydrogen bonds in each of the four structures.

The asymmetric unit of $\mathbf{2 a}$ contains one functionalised calix[4]arene molecule, which has trapped one molecule of $m$-xylene. The final molecular structure is shown in Figure 1. The asymmetric unit of $\mathbf{2 b}$ contains the same functionalised calix[4]arene molecule as in 2a, but this time the calix[4]arene contains one molecule of dimethylformamide (DMF), which is trapped in the upper cavity. The molecular structure is shown in Figure 2. The asymmetric unit of 4 contains one functionalised calix[4]arene molecule, with one molecule of DMF trapped within the upper cavity, similar to that observed in $\mathbf{2 b}$. The final molecular structure is shown in Figure 3. The asymmetric unit of $\mathbf{7}$ consists of two derivatised calix[4]arene molecules and three ethyl acetate solvent molecules. The molecular structure of the functionalised calix[4]arene is shown in Figure 4.

The calix[4]arene is present in all cases in a symmetrical cone conformation, except in the case of $\mathbf{7}$ where the calix[4]arene is present in a slightly flattened cone conformation. The cone conformation in all cases is stabilised by two intramolecular $\mathrm{H}$-bonds between the hydroxyl oxygens and the substituted oxygens, given in Table 3. These values are within the range of previously published values for the intramolecular $\mathrm{H}$-bonds between the hydroxyl oxygens and the substituted oxygens at the lower rim of a calix[4]arene. ${ }^{2 c, 5 f, 14}$ The only other intramolecular H-bonds observed in $\mathbf{2 a}$ and $\mathbf{2 b}$ are between the Schiff-base hydroxyl hydrogens and the imine nitrogens, again within the range of previously published values for the intramolecular H-bonds between the hydroxyl oxygens and imine nitrogen atoms. ${ }^{15}$ In the case of $\mathbf{4}$, one intramolecular $\mathrm{H}$-bond is observed between the ether oxygen (05) and

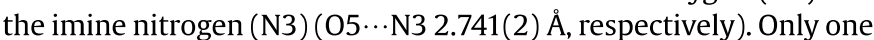
intramolecular bond is observed as a result of the trans nature of the two $\mathrm{C}=\mathrm{N}$ double bonds. This results from the lone pair situated

Table 2

Crystal data and refinement parameters for $\mathbf{2 a}, \mathbf{2 b}, \mathbf{4}$ and $\mathbf{7}$

\begin{tabular}{|c|c|c|c|c|}
\hline & 2a & $\mathbf{2 b}$ & 4 & 7 \\
\hline Empirical formula & $\mathrm{C}_{84} \mathrm{H}_{94} \mathrm{~N}_{4} \mathrm{O}_{8}$ & $\mathrm{C}_{79} \mathrm{H}_{91} \mathrm{~N}_{5} \mathrm{O}_{9}$ & $\mathrm{C}_{65} \mathrm{H}_{79} \mathrm{~N}_{3} \mathrm{O}_{7}$ & $\mathrm{C}_{152} \mathrm{H}_{174} \mathrm{~N}_{16} \mathrm{O}_{18}$ \\
\hline Formula weight & 1287.63 & 1254.57 & 1014.31 & 2513.07 \\
\hline Crystal system & Triclinic & Monoclinic & Monoclinic & Triclinic \\
\hline Space group & $P-1$ & $P 2_{1} / c$ & $P 2_{1} / c$ & $P-1$ \\
\hline \multirow[t]{5}{*}{ Dimensions } & $a=10.8820(1) \AA, \alpha=101.083(1)^{\circ}$ & $a=17.1160(2) \AA, \alpha=90^{\circ}$ & $a=12.6560(1) \AA, \alpha=90^{\circ}$ & $a=17.8530(1) \AA, \alpha=100.136(1)^{\circ}$ \\
\hline & $b=15.1550(1) \AA, \beta=91.568(1)^{\circ}$ & $b=13.4260(1) \AA, \beta=94.738(1)^{\circ}$ & $b=35.8240(3) \AA, \beta=95.486(1)^{\circ}$ & $b=20.9960(2) \AA, \beta=103.846(1)^{\circ}$ \\
\hline & $c=22.8020(1) \AA, \gamma=91.306(1)^{\circ}$ & $c=30.6690(4) \AA, \gamma=90^{\circ}$ & $c=13.2220(1) \AA, \gamma=90^{\circ}$ & $c=21.7370(2) \AA, \gamma=109.330(1)^{\circ}$ \\
\hline & $U=3687.41(5) \AA^{3}$ & $U=7023.63(13) \AA^{3}$ & $U=5967.25(8) \AA^{3}$ & $U=7169.76(10) \AA^{3}$ \\
\hline & $Z=2$ & $Z=4$ & $Z=4$ & $Z=2$ \\
\hline Density (calcd) & $1.160 \mathrm{mg} \mathrm{m}^{-3}$ & $1.186 \mathrm{mg} \mathrm{m}^{-3}$ & $1.129 \mathrm{mg} \mathrm{m}^{-3}$ & $1.164 \mathrm{mg} \mathrm{m}^{-3}$ \\
\hline$\mu$ & $0.074 \mathrm{~mm}^{-1}$ & $0.077 \mathrm{~mm}^{-1}$ & $0.073 \mathrm{~mm}^{-1}$ & $0.077 \mathrm{~mm}^{-1}$ \\
\hline$F(000)$ & 1380 & 2688 & 2184 & 2684 \\
\hline Crystal size & $0.60 \times 0.50 \times 0.50 \mathrm{~mm}$ & $0.25 \times 0.20 \times 0.10 \mathrm{~mm}$ & $0.35 \times 0.20 \times 0.10 \mathrm{~mm}$ & $0.30 \times 0.30 \times 0.25 \mathrm{~mm}$ \\
\hline $\begin{array}{l}\text { Range for data } \\
\text { collection }(\theta)\end{array}$ & $3.51-27.65^{\circ}$ & $3.56-27.49^{\circ}$ & $3.53-27.44^{\circ}$ & $3.86-27.48^{\circ}$ \\
\hline Reflections collected & 56,708 & 101,843 & 82,356 & 136,944 \\
\hline Independent reflections & 16,861 & 16,068 & 13,578 & 32,677 \\
\hline Data/restraints/parameters & $16,861 / 0 / 863$ & $16,068 / 12 / 863$ & $13,578 / 0 / 692$ & $32,677 / 3 / 1731$ \\
\hline Goodness-of-fit & 1.026 & 1.013 & 1.017 & 1.016 \\
\hline Final $R$ indices $[\mathrm{I}>2 \sigma(I)]$ & $R 1=0.0639, w R 2=0.1668$ & $R 1=0.0646, w R 2=0.1336$ & $R 1=0.0554, w R 2=0.1134$ & $R 1=0.0715, w R 2=0.1760$ \\
\hline$R$ indices (all data) & $R 1=0.0860, w R 2=0.1864$ & $R 1=0.1375, w R 2=0.1630$ & $R 1=0.1104, w R 2=0.1355$ & $R 1=0.1207, w R 2=0.2085$ \\
\hline $\begin{array}{l}\text { Largest diff. } \\
\text { peak and hole }\end{array}$ & 1.093 and $-0.562 \mathrm{e}^{-3}$ & 0.343 and -0.376 e $\AA^{-3}$ & 0.400 and -0.331 e $\AA^{-3}$ & 1.031 and $-0.476 \mathrm{e}^{-3}$ \\
\hline Deposition number & CCDC 692925 & CCDC 692926 & CCDC 692927 & CCDC 692928 \\
\hline
\end{tabular}


Table 3

Intramolecular hydrogen bond distances for structures $\mathbf{2 a}, \mathbf{2 b}, \mathbf{4}$ and $\mathbf{7}$

\begin{tabular}{lll}
\hline & $\mathrm{O} \cdots \mathrm{O}(\AA)$ & $\mathrm{O} \cdots \mathrm{N}(\AA)$ \\
\hline $\mathbf{2 a}$ & $2.809(2), 2.797(2)$ & $2.641(2), 2.642(2)$ \\
$\mathbf{2 b}$ & $2.706(2), 2.747(2)$ & $2.678(3), 2.564(6)$ \\
$\mathbf{4}$ & $2.673(2), 2.740(2)$ & $2.741(2)$ \\
$\mathbf{7}$ & $2.797(2), 2.991(2)$ & - \\
\hline
\end{tabular}

on the second nitrogen of the double bond pointing away from the other ether oxygen atom ( 02$)$. A similar situation was reported by Sukwattanasinitt and co-workers in their study of azobenzenebridged crown ether calix[4]arenes. ${ }^{16}$

Inclusion solvent molecules are observed in $\mathbf{2 a}, \mathbf{2 b}$ and $\mathbf{4}$. The average distance between the centroid of the $m$-xylene fragments and the centroids of the two calix[4]arene phenyl rings is $4.9 \AA$. The position of the $m$-xylene molecule led us to believe that this was responsible for the bending away of the pendant arms of the calix[4]arene derivative in the manner shown in Figure 1. In order to observe the role played by the solvent in the structural conformation, we decided to change the solvent to DMF and see if this new host-guest interaction would result in a different conformation of the pendant arms.

The cone conformation of $\mathbf{2} \mathbf{b}$ helps in the formation of an intercavity inclusion complex with a molecule of DMF. Several inclusion complexes of DMF in calix[4]arene derivatives have been reported previously. ${ }^{17}$ The DMF molecule, in this case, is positioned inside the upper cavity of the calix[4]arene in such a manner that one of the $N$-methyl groups points directly into the cavity while the $\mathrm{C}=\mathrm{O}$ group is pointing away from the cavity, as Takemura and coworkers had observed in the DMF inclusion complexes of homoazacalix[4]arenes. ${ }^{17 \mathrm{~b}} \mathrm{~A} \mathrm{CH} \cdots \pi$ interaction between an N-Me group of the DMF and the benzene ring of the calix[4]arene was clearly observed, as indicated by the short contacts between the N-Me carbon (C79) and its protons and the aromatic rings. Table 4 summarises these short contacts. Furthermore, although the solvent is now included in a different position, compared to that of the $m$ xylene molecule, the same folding of the pendant arms is observed. The $\mathrm{CH} \cdots \pi$ interaction between an N-Me group of the DMF and the benzene ring of the calix[4]arene in $\mathbf{4}$ was again clearly observed, and is summarised in Table 4.

An interesting feature of the crystal structures $\mathbf{2 a}, \mathbf{2 b}$ and $\mathbf{7}$ is that the two pendant arms do not exist in a face-to-face orientation, but instead are bent away from each other. This type of orientation has been previously observed by Kim and co-workers ${ }^{18}$ in their papers on pyrene-containing calix[4]arene derivatives and by Beer and co-workers. ${ }^{19}$ However, their functionalised calix[4]arenes are attached to the lower rim by means of an amide bond. The hydrogen atom of this amide bond formed an intramolecular H-bond with the oxygen atom of the phenolic hydroxyl group in the calix[4] arene ring. This H-bond, along with the H-bonds formed between the phenolic hydrogens and the phenol ethers to give the cone conformation, combined to orient both the pyrene groups ${ }^{18}$ and the ferrocene groups ${ }^{19}$ away from each other in both cases. This cannot be the reason in our cases as there are no amide bonds present in either of the three structures. Furthermore, the effect of

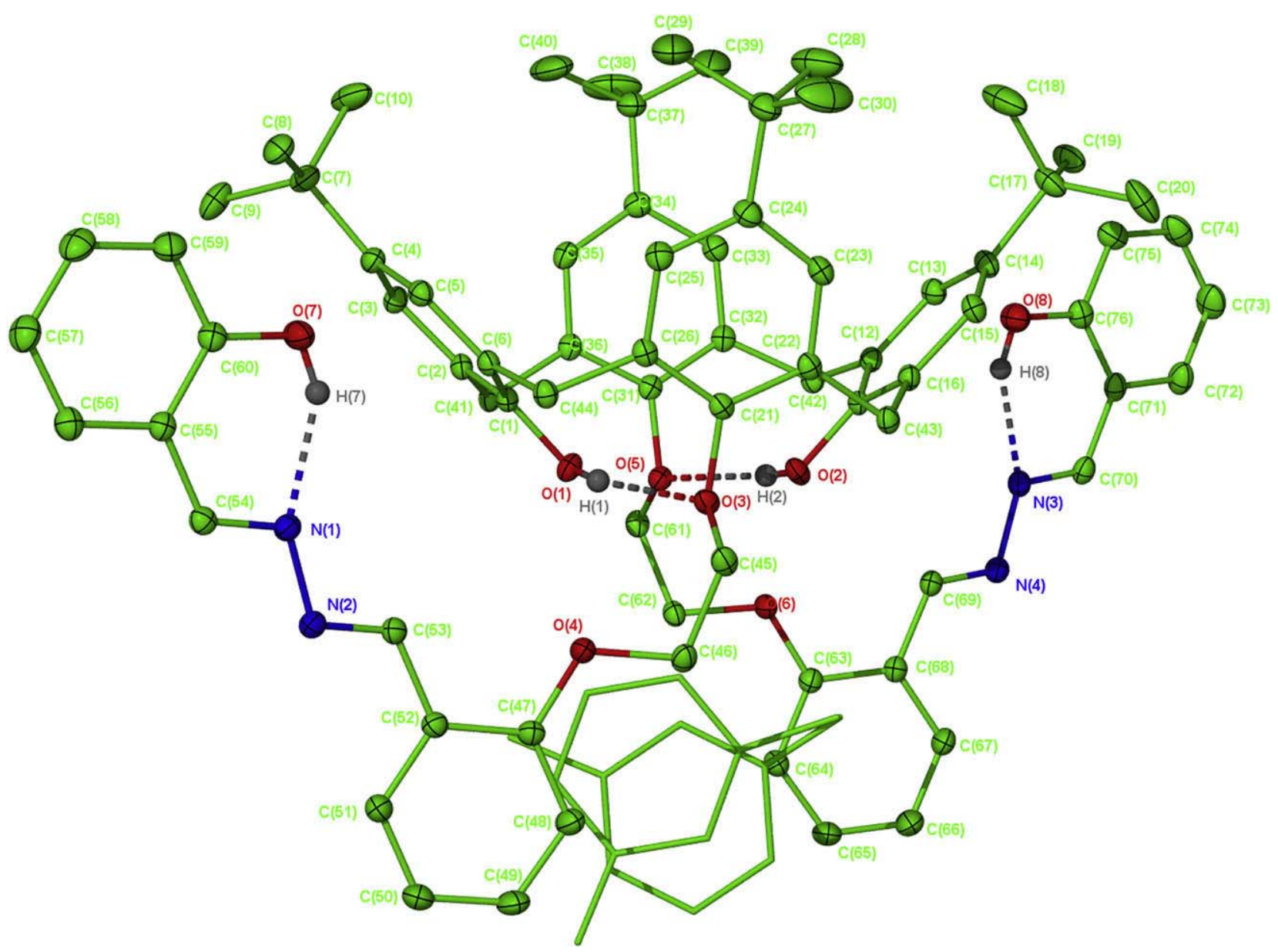

Figure 1. Molecular structure of 2a showing selected labels. Hydrogens from functionalities that do not contribute to hydrogen bonding with the asymmetric unit are omitted for clarity. Ellipsoids are displayed at the $30 \%$ probability level. 


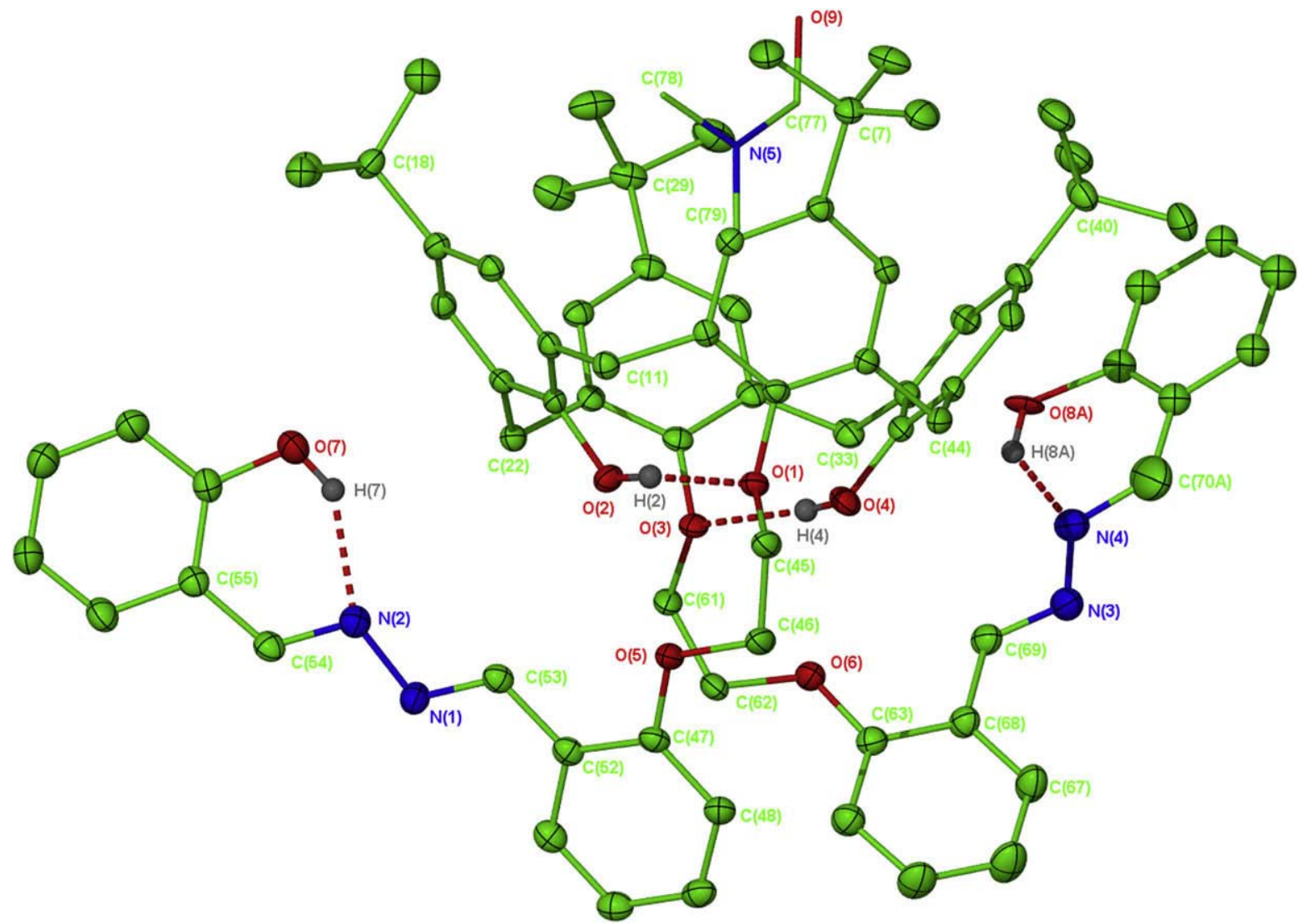

Figure 2. Molecular structure of $\mathbf{2 b}$ showing selected labels. Hydrogens from functionalities that do not contribute to hydrogen bonding with the asymmetric unit are omitted for clarity. Ellipsoids are displayed at the $30 \%$ probability level.

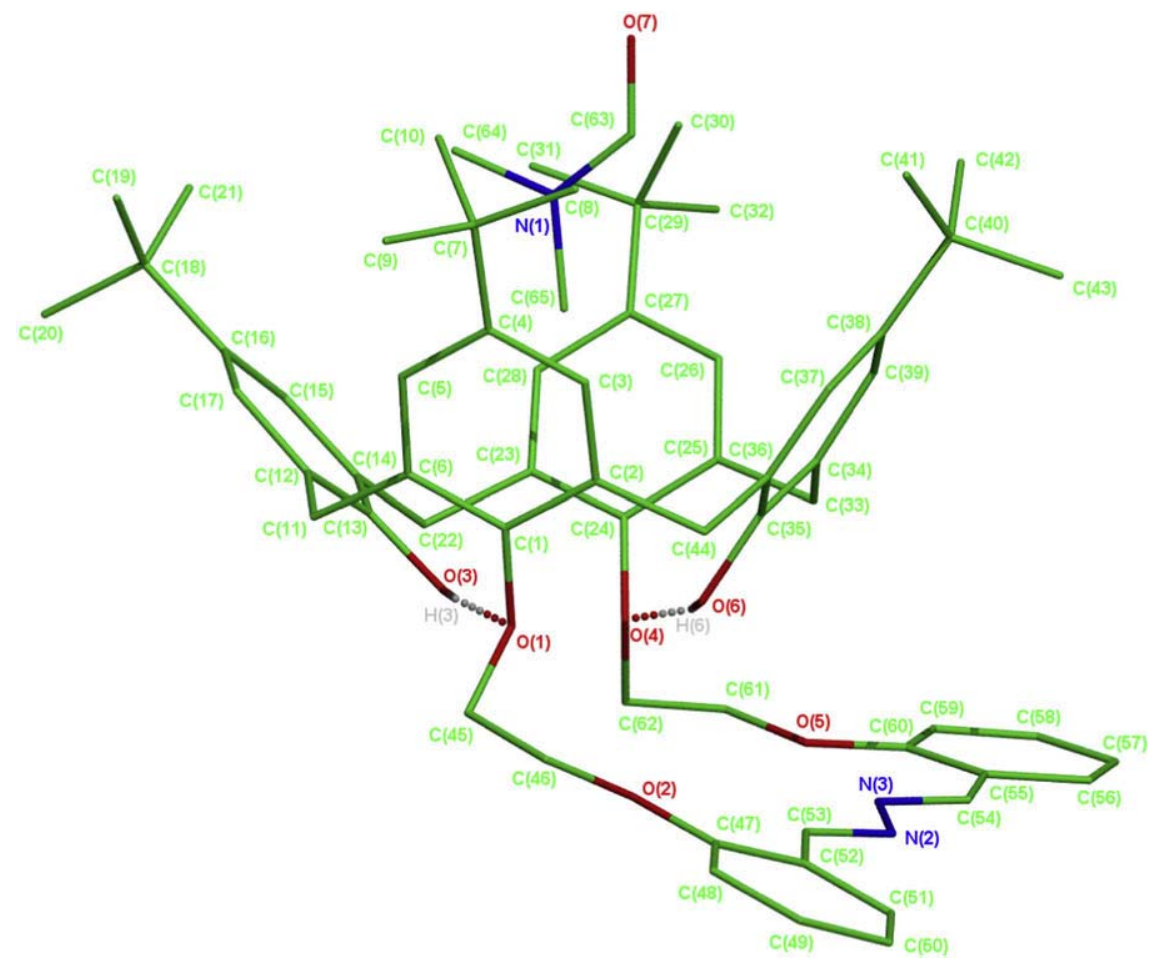

Figure 3. Molecular structure of $\mathbf{4}$ showing selected labels. Hydrogens from functionalities that do not contribute to hydrogen bonding with the asymmetric unit are omitted for clarity. Ellipsoids are displayed at the $30 \%$ probability level. 


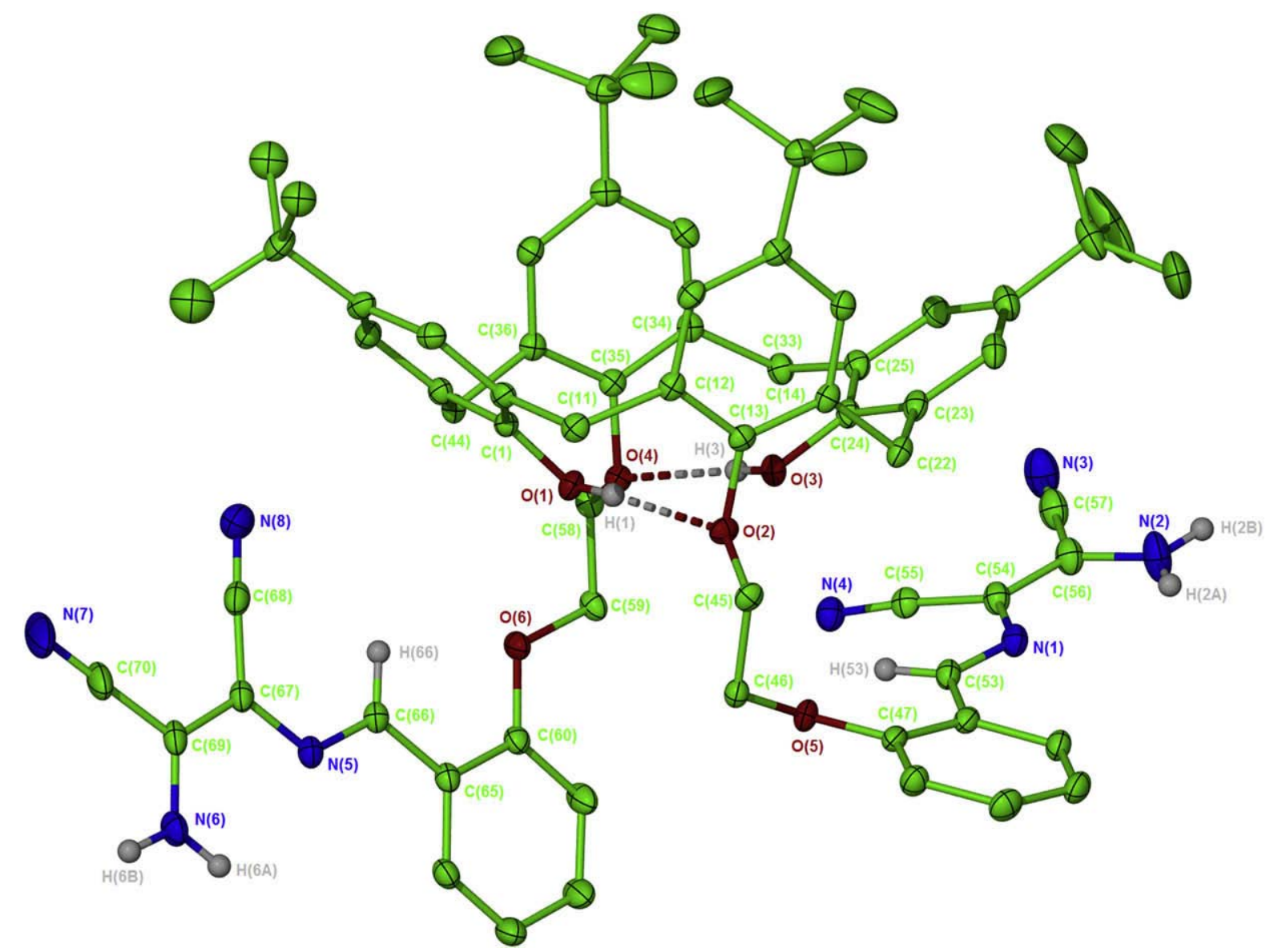

Figure 4. Molecular structure of $\mathbf{7}$ showing selected labels. Hydrogens from functionalities that do not contribute to hydrogen bonding with the asymmetric unit are omitted for clarity. Ellipsoids are displayed at the $30 \%$ probability level.

included solvent molecules can be excluded as the X-ray crystal structures of 2 containing $m$-xylene and DMF were obtained, and although the solvent was found in two different inclusion sites, the folding away of the pendant arms resulted in both cases. One possible explanation is steric interactions. The pendant arms are bent away from each other since if they were in a face-to-face conformation then the arms would be in very close proximity and would probably collide with each other. However, a possible answer for this orientation can be found when the space-filled diagrams are considered. Figure 5 shows the space-filled diagram for structure $\mathbf{2 a}$ as viewed from beneath. The $m$-xylene molecule is shown in orange while the carbon, nitrogen and oxygen atoms are in green, blue and red, respectively. This view shows that the two oxygen atoms ( 05 and 06 ), which are connected by two methylene units, are in close proximity to each other with a distance of $2.91 \AA$ separating the two atoms. Where hydrogen bonding is possible within the pendant groups, it is exploited in the solid-state

Table 4

Distances between N-Me and benzene rings $(\AA)$, shown to two decimal places

\begin{tabular}{lllll}
\hline & $\mathrm{Me}(\mathrm{DMF}) \cdots \pi$ plane 1 & \multicolumn{2}{l}{$\mathrm{Me}(\mathrm{DMF}) \cdots \pi$ plane 2} \\
\hline $\mathbf{2 b}$ & $\mathrm{C}(79)$ & 3.73 and 3.91 & $\mathrm{C}(79)$ & $x . x$ \\
& $\mathrm{H}(79 \mathrm{C})$ & 2.76 & $\mathrm{H}(79 \mathrm{~A})$ & 2.78 \\
$\mathbf{4}$ & $\mathrm{C}(65)$ & 3.84 and 3.92 & $\mathrm{C}(65)$ & $x . x$ \\
& $\mathrm{H}(65 \mathrm{C})$ & 2.88 & $\mathrm{H}(65 \mathrm{~A})$ & 2.86 \\
\hline
\end{tabular}

Plane 1 of $\mathbf{2 b}$ : $\mathrm{C}(1)-\mathrm{C}(2)-\mathrm{C}(3)-\mathrm{C}(4)-\mathrm{C}(5)-\mathrm{C}(6)$.

Plane 2 of $\mathbf{2 b}: C(34)-C(35)-C(36)-C(37)-C(38)-C(39)$.

Plane 1 of 4: $C(1)-C(2)-C(3)-C(4)-C(5)-C(6)$

Plane 2 of 4: $C(34)-C(35)-C(36)-C(37)-C(38)-C(39)$. structure and the resulting conformation utilises it. Analysis of the supramolecular arrays in all cases does not afford additional insight in the pendant orientations. The molecules pack in a way that gives low energy solid-state structures, with no obvious $\pi-\pi$ stacking. A second feature of the crystal structures $\mathbf{2 a}, \mathbf{2} \mathbf{b}$ and $\mathbf{7}$ is that if the methylene groups are ignored, the pendant arms are almost planar. This planarity suggests that there is extended $\pi$-conjugation throughout the functionalised arm. This type of $\pi$-conjugation has been previously reported for calix[4]arenes at both the upper and the lower rims. ${ }^{20}$

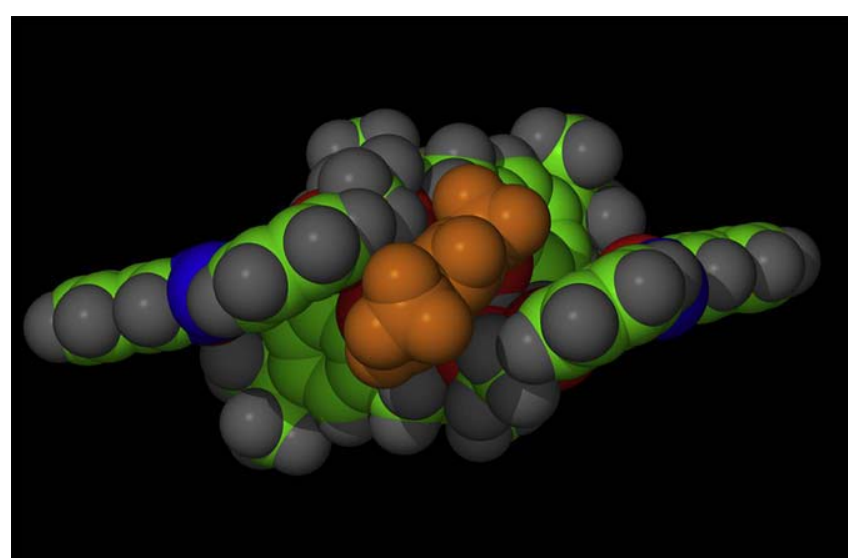

Figure 5. Space-filled view of 2a showing proximity of oxygen atoms (shown in red). 


\section{Conclusion}

The Schiff-base reactions between $\mathbf{1}$ and various amines or hydrazones resulted in a series of pendant Schiff-base calix[4]arene derivatives. X-ray crystallographic studies of three of these confirmed both the cone conformation of the calix[4]arene and the imine formation. They also showed that the pendant arms did not adopt a face-to-face conformation but instead were bent away from each other. These conformations were brought about by steric constrictions, as well as the formation of additional intramolecular interactions between hydroxyl groups on the pendant arms and an aromatic ring of the calix[4]arene.

\section{Experimental}

\subsection{General}

${ }^{1} \mathrm{H}$ and ${ }^{13} \mathrm{C} \mathrm{NMR}(\delta \mathrm{ppm}, J \mathrm{~Hz})$ spectra were recorded on a Bruker Avance $300 \mathrm{MHz}$ NMR spectrometer using saturated $\mathrm{CDCl}_{3}$ solutions with $\mathrm{Me}_{4} \mathrm{Si}$ reference, unless indicated otherwise, with resolutions of $0.18 \mathrm{~Hz}$ and $0.01 \mathrm{ppm}$, respectively. Infrared spectra $\left(\mathrm{cm}^{-1}\right)$ were recorded as $\mathrm{KBr}$ discs or liquid films between $\mathrm{KBr}$ plates using a Perkin Elmer System 2000 FT-IR spectrometer. Melting point analyses were carried out using a Stewart Scientific SMP 1 melting point apparatus and are uncorrected. Microanalysis was carried out at the Microanalytical Laboratory of either University College, Dublin or the National University of Ireland Cork. Standard Schlenk techniques were used throughout. Starting materials were commercially obtained and used without further purification.

\subsection{Synthetic procedures}

The synthesis of compounds $\mathbf{1}^{7}{ }^{0}$-vanillin hydrazone ${ }^{8}$ and pyridine hydrazone ${ }^{9}$ has been described in the literature previously.

\subsubsection{Compound 1}

The ortho-substituted dialdehyde calix[4]arene 1 was prepared as described in the literature; ${ }^{7} \delta_{\mathrm{H}}\left(300 \mathrm{MHz}, \mathrm{CDCl}_{3}, \mathrm{Me}_{4} \mathrm{Si}\right) 1.02$ (18H, s, $t-\mathrm{Bu}), 1.25$ (18H, s, $t-\mathrm{Bu}), 3.31\left(4 \mathrm{H}, \mathrm{d}, J=12.9, \mathrm{ArCH} \mathrm{Ar}_{2} \mathrm{Ar}, 4.30\right.$ $\left(4 \mathrm{H}, \mathrm{d}, \mathrm{J}=12.9, \mathrm{ArCH} \mathrm{Ar}_{2}\right), 4.40\left(8 \mathrm{H}, \mathrm{m}, \mathrm{OCH}_{2} \mathrm{CH}_{2} \mathrm{O}\right), 6.88(4 \mathrm{H}, \mathrm{s}, \mathrm{Ar}-$ $H), 7.0(4 \mathrm{H}, \mathrm{m}, \mathrm{Ar}-\mathrm{H}), 7.02(4 \mathrm{H}, \mathrm{s}, \mathrm{Ar}-\mathrm{H}), 7.49(2 \mathrm{H}, \mathrm{s}$, calix-OH), 7.50 $(2 \mathrm{H}, \mathrm{m}, \mathrm{Ar}-\mathrm{H}), 7.83(2 \mathrm{H}, \mathrm{m}, \mathrm{Ar}-\mathrm{H}), 10.50(2 \mathrm{H}, \mathrm{s}, \mathrm{HC}=\mathrm{O}) ; \delta_{\mathrm{C}}(75 \mathrm{MHz}$ $\mathrm{CDCl}_{3}, \mathrm{Me}_{4} \mathrm{Si}$ ) 31.1, 31.7, 31.8, 33.8, 34.0, 67.5, 73.6, 112.4, 121.0, 125.2, $125.8,127.8,128.3,132.7,135.8,141.8,147.4,149.8,150.3,160.8$ 190.2

\subsection{2. o-Vanillin hydrazone}

$o$-Vanillin $(1.0 \mathrm{~g}, 6.57 \mathrm{mmol})$ in ethanol $(40 \mathrm{~mL})$ was added dropwise, over $20 \mathrm{~min}$, to hydrazine hydrate $(1.64 \mathrm{~g}, 32.86 \mathrm{mmol})$ in ethanol $(10 \mathrm{~mL})$. The yellow solution was stirred for $1 \mathrm{~h}$, after which time the solvent was removed under reduced pressure to leave a yellow oil. On standing, the oil crystallised into a yellow solid, which was analysed as the required product $(1.07 \mathrm{~g}, 88 \%), \mathrm{mp}$ $168-170^{\circ} \mathrm{C} ; \nu_{\max }(\mathrm{KBr}) / \mathrm{cm}^{-1} 3380,1620,1576,1468,1320,1246$, $1090,964,838,776,625 ; \delta_{\mathrm{H}}\left(300 \mathrm{MHz}, \mathrm{CDCl}_{3}, \mathrm{Me}_{4} \mathrm{Si}\right) 3.90(3 \mathrm{H}, \mathrm{s}$, $\left.\mathrm{OCH}_{3}\right), 5.46\left(2 \mathrm{H}, \mathrm{s}, \mathrm{NH}_{2}\right), 6.87-6.72(3 \mathrm{H}, \mathrm{m}, \mathrm{Ar}-\mathrm{H}), 7.86(1 \mathrm{H}, \mathrm{s}$, $H C=\mathrm{N}), 11.20(1 \mathrm{H}, \mathrm{s}, \mathrm{OH}) ; \delta_{\mathrm{C}}\left(75 \mathrm{MHz}, \mathrm{CDCl}_{3}, \mathrm{Me}_{4} \mathrm{Si}\right)$ 56.1, 112.3, 118.6, 118.8, 121.2, 146.6, 147.3, 148.1 .

\subsubsection{2-Pyridine hydrazone}

2-Pyridinecarboxaldehyde $(0.5 \mathrm{~g}, 4.67 \mathrm{mmol})$ in ethanol $(30 \mathrm{~mL})$ was added dropwise, over $20 \mathrm{~min}$, to hydrazine hydrate $(0.7 \mathrm{~g}$, $14.0 \mathrm{mmol})$ in ethanol $(10 \mathrm{~mL})$. The yellow solution was stirred for $12 \mathrm{~h}$, after which time the solvent was removed under reduced pressure to leave a yellow/brown oil, which was analysed as the required product $(0.58 \mathrm{~g}, 91 \%) ; \nu_{\max }(\mathrm{KBr}) / \mathrm{cm}^{-1} 3368,3181,1583$, $1565,1473,1389,1150,993,776,622 ; \delta_{\mathrm{H}}\left(300 \mathrm{MHz}, \mathrm{CDCl}_{3}, \mathrm{Me}_{4} \mathrm{Si}\right)$ $5.83\left(2 \mathrm{H}, \mathrm{br} \mathrm{s}, \mathrm{NH}_{2}\right), 7.17(1 \mathrm{H}, \mathrm{m}, \mathrm{Ar}-\mathrm{H}), 7.65(1 \mathrm{H}, \mathrm{m}, \mathrm{Ar}-\mathrm{H}), 7.77(1 \mathrm{H}$, $\mathrm{m}, \mathrm{Ar}-\mathrm{H}), 7.83(1 \mathrm{H}, \mathrm{s}, H \mathrm{C}=\mathrm{N}), 8.54(1 \mathrm{H}, \mathrm{m}, \mathrm{Ar}-\mathrm{H}) ; \delta_{\mathrm{C}}(75 \mathrm{MHz}$, $\left.\mathrm{CDCl}_{3}, \mathrm{Me}_{4} \mathrm{Si}\right)$ 119.7, 122.8, 136.3, 142.6, 149.2, 154.3 .

\subsubsection{Compound 2}

The ortho-substituted dialdehyde calix[4]arene 1 (2.0 g, $2.1 \mathrm{mmol})$ in absolute ethanol $(50 \mathrm{~mL})$ and acetic acid $(2 \mathrm{~mL})$ and salicylaldehyde hydrazone $(0.69 \mathrm{~g}, 5.1 \mathrm{mmol})$ in absolute ethanol $(100 \mathrm{~mL})$ were stirred at room temperature for $24 \mathrm{~h}$. The resulting yellow precipitate was removed by filtration, washed with ethanol and dried in the oven to give $\mathbf{2}$-hemihydrate $(2.18 \mathrm{~g}, 87 \%)$ as a yellow solid, mp $166-168{ }^{\circ} \mathrm{C}$. (Found: $\mathrm{C}, 76.80 ; \mathrm{H}, 6.94 ; \mathrm{N}, 4.66$. $\left(\mathrm{C}_{76} \mathrm{H}_{84} \mathrm{~N}_{8} \mathrm{O}_{8}\right)_{2} \cdot \mathrm{H}_{2} \mathrm{O}$ requires: C, 76.67; $\mathrm{H}, 7.20 ; \mathrm{N}, 4.71 \%$. $) \nu_{\max }(\mathrm{KBr}) /$ $\mathrm{cm}^{-1} 3457,3354,2956,2887,1624,1603,1576,1486,1274,1056$, $750 ; \delta_{\mathrm{H}}\left(300 \mathrm{MHz}, \mathrm{CDCl}_{3}, \mathrm{Me}_{4} \mathrm{Si}\right) 1.00(18 \mathrm{H}, \mathrm{s}, t-\mathrm{Bu}), 1.17(18 \mathrm{H}, \mathrm{s}$, $t-\mathrm{Bu}$ ), $3.27\left(4 \mathrm{H}, \mathrm{d}, J=13.0, \mathrm{ArCH} \mathrm{Ar}_{2}\right), 4.33$ (4H, d, $J=13.0, \mathrm{ArCH}_{2} \mathrm{Ar}$ ), $4.40\left(8 \mathrm{H}, \mathrm{m}, \mathrm{OCH}_{2} \mathrm{CH}_{2} \mathrm{O}\right), 6.85(4 \mathrm{H}, \mathrm{s}, \mathrm{Ar}-\mathrm{H}), 6.91(2 \mathrm{H}, \mathrm{m}, \mathrm{Ar}-\mathrm{H}), 6.96$ $(4 \mathrm{H}, \mathrm{s}, \mathrm{Ar}-\mathrm{H}), 7.02(6 \mathrm{H}, \mathrm{m}, \mathrm{Ar}-\mathrm{H}), 7.27(2 \mathrm{H}, \mathrm{m}, \mathrm{Ar}-\mathrm{H}), 7.33(2 \mathrm{H}, \mathrm{m}$, $\mathrm{Ar}-\mathrm{H}), 7.42(2 \mathrm{H}, \mathrm{m}, \mathrm{Ar}-\mathrm{H}), 7.46(2 \mathrm{H}, \mathrm{s}, \mathrm{calix}-\mathrm{OH}), 8.08(2 \mathrm{H}, \mathrm{m}, \mathrm{Ar}-\mathrm{H})$, $8.64(2 \mathrm{H}, \mathrm{s}, \mathrm{HC}=\mathrm{N}), 9.12(2 \mathrm{H}, \mathrm{s}, H \mathrm{C}=\mathrm{N}), 11.71(2 \mathrm{H}, \mathrm{s}, \mathrm{Ar}-\mathrm{OH}) ; \delta_{\mathrm{C}}$ (75 MHz, $\left.\mathrm{CDCl}_{3}, \mathrm{Me}_{4} \mathrm{Si}\right)$ 31.0, 31.6, 31.7, 33.7, 34.0, 67.2, 73.6, 112.0, $116.9,117.8,119.2,121.1,122.6,125.1,125.7,127.5,127.7,132.2,132.6$, $132.8,132.9,141.5,147.2,149.6,150.3,158.2,158.4,159.9,164.1$.

\subsubsection{Compound 3}

A solution of dialdehyde calix[4]arene $1(0.5 \mathrm{~g}, 0.5 \mathrm{mmol})$ in acetonitrile $(50 \mathrm{~mL})$ was added dropwise, over $20 \mathrm{~min}$, to hydrazine hydrate $(0.53 \mathrm{~g}, 10.6 \mathrm{mmol})$. The resulting pale yellow solution was stirred for $12 \mathrm{~h}$. After this time, the solvent was removed under reduced pressure and the residue was treated with ethanol $(20 \mathrm{~mL})$ from which a white solid precipitated. This solid was removed by filtration, washed with ethanol and dried in the oven to give 3 $(0.40 \mathrm{~g}, 76 \%)$ as a white solid, $\mathrm{mp} 218-220^{\circ} \mathrm{C}$. (Found: C, 76.52; $\mathrm{H}$, 7.87; N, 5.94. $\mathrm{C}_{62} \mathrm{H}_{76} \mathrm{~N}_{4} \mathrm{O}_{6}$ requires: $\mathrm{C}, 76.51 ; \mathrm{H}, 7.87 ; \mathrm{N}, 5.75 \%$.) $\nu_{\max }$ $(\mathrm{KBr}) / \mathrm{cm}^{-1} 3534,3378,2961,1687,1600,1485,1289,1058,924$, $756 ; \delta_{\mathrm{H}}\left(300 \mathrm{MHz}, \mathrm{CDCl}_{3}, \mathrm{Me}_{4} \mathrm{Si}\right) 1.00(18 \mathrm{H}, \mathrm{s}, t-\mathrm{Bu}), 1.27(18 \mathrm{H}, \mathrm{s}$, $t-\mathrm{Bu}), 3.33\left(4 \mathrm{H}, \mathrm{d}, J=13.0, \mathrm{ArCH} \mathrm{Ar}_{2}, 4.24\left(8 \mathrm{H}, \mathrm{m}, \mathrm{OCH}_{2} \mathrm{CH}_{2} \mathrm{O}\right), 4.39\right.$ $\left(4 \mathrm{H}, \mathrm{d}, J=13.0, \mathrm{ArCH} \mathrm{H}_{2} \mathrm{Ar}\right), 4.95\left(4 \mathrm{H}, \mathrm{br} \mathrm{s}, \mathrm{NH}_{2}\right), 6.72(2 \mathrm{H}, \mathrm{m}, \mathrm{Ar}-\mathrm{H})$, $6.85(4 \mathrm{H}, \mathrm{s}, \mathrm{Ar}-\mathrm{H}), 6.93(2 \mathrm{H}, \mathrm{m}, \mathrm{Ar}-\mathrm{H}), 7.06(4 \mathrm{H}, \mathrm{s}, \mathrm{Ar}-\mathrm{H}), 7.17(2 \mathrm{H}$, $\mathrm{m}, \mathrm{Ar}-\mathrm{H}), 7.75(2 \mathrm{H}, \mathrm{m}, \mathrm{Ar}-\mathrm{H}), 7.77(2 \mathrm{H}, \mathrm{s}, \mathrm{calix}-\mathrm{OH}), 8.21(2 \mathrm{H}, \mathrm{s}$, $H C=\mathrm{N}) ; \delta_{\mathrm{C}}\left(75 \mathrm{MHz}, \mathrm{CDCl}_{3}, \mathrm{Me}_{4} \mathrm{Si}\right) 31.1,31.7,33.9,34.0,66.8,74.2$, $111.7,121.1,124.2,125.3,125.6,125.7,127.6,129.6,132.6,139.7,141.7$, $147.2,149.6,150.7,155.8$.

\subsubsection{Compound 4}

A solution of dialdehyde calix[4]arene $1(1.0 \mathrm{~g}, 1.06 \mathrm{mmol})$ and salicylaldehyde hydrazone $(0.6 \mathrm{~g}, 4.43 \mathrm{mmol})$ was heated to reflux in ethanol $(60 \mathrm{~mL})$ for $3 \mathrm{~h}$. On cooling, a yellow solid precipitated, which was removed by filtration, washed with ethanol and dried in the oven to give 4 . hydrate $(0.45 \mathrm{~g}, 46 \%)$ as a yellow solid, mp 210 $212{ }^{\circ} \mathrm{C}$ (Found: $\mathrm{C}, 77.67 ; \mathrm{H}, 7.59 ; \mathrm{N}, 2.69 . \mathrm{C}_{62} \mathrm{H}_{74} \mathrm{~N}_{2} \mathrm{O}_{7}$ requires: $\mathrm{C}$, 77.63; H, 7.78; N, 2.92\%.) $\nu_{\max }(\mathrm{KBr}) / \mathrm{cm}^{-1} 3435,2960,1621,1601$, $1485,1253,1161,1052,751 ; \delta_{\mathrm{H}}\left(300 \mathrm{MHz}, \mathrm{CDCl}_{3}, \mathrm{Me}_{4} \mathrm{Si}\right) 0.92(18 \mathrm{H}, \mathrm{s}$, $t$-Bu), $1.23(18 \mathrm{H}, \mathrm{s}, t-\mathrm{Bu}), 3.11\left(4 \mathrm{H}, \mathrm{d}, J=12.9, \mathrm{ArCH}_{2} \mathrm{Ar}\right), 4.31(4 \mathrm{H}, \mathrm{d}$, $\left.\mathrm{J}=12.9, \mathrm{ArCH}_{2} \mathrm{Ar}\right), 4.45\left(8 \mathrm{H}, \mathrm{m}, \mathrm{OCH}_{2} \mathrm{CH}_{2} \mathrm{O}\right), 6.78(4 \mathrm{H}, \mathrm{s}, \mathrm{Ar}-\mathrm{H}), 6.88$ $(2 \mathrm{H}, \mathrm{m}, \mathrm{Ar}-\mathrm{H}), 6.94(4 \mathrm{H}, \mathrm{s}, \mathrm{Ar}-\mathrm{H}), 7.01(2 \mathrm{H}, \mathrm{m}, \mathrm{Ar}-\mathrm{H}), 7.28(2 \mathrm{H}, \mathrm{s}$, calix-OH), $7.36(2 \mathrm{H}, \mathrm{m}, \mathrm{Ar}-\mathrm{H}), 7.82(2 \mathrm{H}, \mathrm{m}, \mathrm{Ar}-\mathrm{H}), 9.02(2 \mathrm{H}, \mathrm{s}$, $H C=\mathrm{N}) ; \delta_{\mathrm{C}}\left(75 \mathrm{MHz}, \mathrm{CDCl}_{3}, \mathrm{Me}_{4} \mathrm{Si}\right) 31.0,31.1,31.7,33.7,38.9,65.7$, 73.6, 111.6, 120.9, 123.7, 124.8, 125.5, 127.7, 130.9, 131.5, 133.0, 141.0, $146.9,149.0,150.6,157.2,157.3$.

A solution of 3 ( $50 \mathrm{mg}, 0.05 \mathrm{mmol}$ ) was heated to reflux, under nitrogen, in ethanol $(8 \mathrm{~mL})$ for $12 \mathrm{~h}$, which resulted in a yellow suspension. On cooling, the suspension was removed by filtration, washed with ethanol and dried in the oven to give 4 -hydrate 
(45 mg, 88\%) as a yellow solid, which gave identical IR and NMR spectroscopic data to that outlined already.

\subsubsection{Compound 5}

A solution of dialdehyde calix[4]arene $1(0.36 \mathrm{~g}, 0.38 \mathrm{mmol})$ and $o$-vanillin hydrazone $(0.18 \mathrm{~g}, 0.98 \mathrm{mmol})$ in ethanol $(20 \mathrm{~mL})$ was heated to reflux, under nitrogen, for $1 \mathrm{~h}$. The pale yellow suspension was allowed to cool and the resulting solid was removed by filtration, washed with ethanol and dried in the oven to give 5 - dihydrate $(0.31 \mathrm{~g}, 64 \%)$ as a yellow solid, $\mathrm{mp} 226-228^{\circ} \mathrm{C}$. (Found: C, 73.45; $\mathrm{H}, 7.08 ; \mathrm{N}, 4.61 . \mathrm{C}_{78} \mathrm{H}_{88} \mathrm{~N}_{4} \mathrm{O}_{10}$ requires: $\mathrm{C}, 73.32 ; \mathrm{H}, 7.26 ; \mathrm{N}$, $4.39 \%$.) $\nu_{\max }(\mathrm{KBr}) / \mathrm{cm}^{-1} 3376,2961,1682,1560,1459,1394,1248$, $1075,923,756 ; \delta_{\mathrm{H}}\left(300 \mathrm{MHz}, \mathrm{CDCl}_{3}, \mathrm{Me}_{4} \mathrm{Si}\right) 0.93$ (18H, s, $\left.t-\mathrm{Bu}\right), 1.23$ (18H, s, $t-\mathrm{Bu}), 3.12\left(4 \mathrm{H}, \mathrm{d}, J=12.8, \mathrm{ArCH}_{2} \mathrm{Ar}\right), 3.94\left(6 \mathrm{H}, \mathrm{s}, \mathrm{OCH}_{3}\right), 4.31$ $\left(4 \mathrm{H}, \mathrm{d}, \mathrm{J}=12.8, \mathrm{ArCH}_{2} \mathrm{Ar}\right), 4.44\left(8 \mathrm{H}, \mathrm{m}, \mathrm{OCH}_{2} \mathrm{CH}_{2} \mathrm{O}\right), 6.78(4 \mathrm{H}, \mathrm{s}, \mathrm{Ar}-$ $H), 6.91(4 \mathrm{H}, \mathrm{m}, \mathrm{Ar}-H), 6.93(4 \mathrm{H}, \mathrm{s}, \mathrm{Ar}-H), 7.03(4 \mathrm{H}, \mathrm{m}, \mathrm{Ar}-H), 7.35$ $(2 \mathrm{H}, \mathrm{s}$, calix-OH $), 7.37(2 \mathrm{H}, \mathrm{m}, \mathrm{Ar}-\mathrm{H}), 7.83(2 \mathrm{H}, \mathrm{m}, \mathrm{Ar}-\mathrm{H}), 8.71(2 \mathrm{H}, \mathrm{s}$, $\mathrm{HC}=\mathrm{N}), 9.03(2 \mathrm{H}, \mathrm{s}, \mathrm{HC}=\mathrm{N}), 11.57(2 \mathrm{H}, \mathrm{s}, \mathrm{OH}) ; \delta_{\mathrm{C}}\left(75 \mathrm{MHz}, \mathrm{CDCl}_{3}\right.$, $\left.\mathrm{Me}_{4} \mathrm{Si}\right)$ 31.0, 31.1, 31.7, 33.7, 33.9, 56.2, 65.7, 73.6, 111.6, 115.1, 117.3, $119.4,120.9,123.7,124.0,124.8,125.5,127.6,131.0,131.5,133.0$, $140.9,146.9,148.3,149.0,150.6,157.2,157.3,164.8$.

\subsubsection{Compound 6}

A solution of calix[4]arene $3(0.54 \mathrm{~g}, 0.57 \mathrm{mmol})$ and 2-pyridine hydrazone $(0.43 \mathrm{~g}, 3.1 \mathrm{mmol})$ was stirred in ethanol $(40 \mathrm{~mL})$ for 4 days at room temperature. The resulting yellow suspension was removed by filtration, washed with ethanol and dried in an oven to give $6(0.42 \mathrm{~g}, 63 \%)$ as a yellow solid, $\mathrm{mp} 166-168^{\circ} \mathrm{C}$. (Found: $\mathrm{C}$, 76.88; $\mathrm{H}, 7.09 ; \mathrm{N}, 6.99 . \mathrm{C}_{74} \mathrm{H}_{82} \mathrm{~N}_{6} \mathrm{O}_{6}$ requires: $\mathrm{C}, 77.17 ; \mathrm{H}, 7.18 ; \mathrm{N}$, 7.29\%.) $\nu_{\max }(\mathrm{KBr}) / \mathrm{cm}^{-1} 3348,2959,1690,1602,1485,1450,1250$, 1058,$752 ; \delta_{\mathrm{H}}\left(300 \mathrm{MHz}, \mathrm{CDCl}_{3}, \mathrm{Me}_{4} \mathrm{Si}\right) 1.01(18 \mathrm{H}, \mathrm{s}, t-\mathrm{Bu}), 1.21(18 \mathrm{H}$, $\mathrm{s}, t-\mathrm{Bu}), 3.28\left(4 \mathrm{H}, \mathrm{d}, J=12.9, \mathrm{ArCH}_{2} \mathrm{Ar}\right), 4.36\left(4 \mathrm{H}, \mathrm{d}, J=12.9, \mathrm{ArCH}_{2} \mathrm{Ar}\right)$, $4.37\left(8 \mathrm{H}, \mathrm{m}, \mathrm{OCH}_{2} \mathrm{CH}_{2} \mathrm{O}\right), 6.87(4 \mathrm{H}, \mathrm{s}, \mathrm{Ar}-\mathrm{H}), 6.92(2 \mathrm{H}, \mathrm{m}, \mathrm{Ar}-\mathrm{H}), 6.97$ $(4 \mathrm{H}, \mathrm{s}, \mathrm{Ar}-\mathrm{H}), 7.03(2 \mathrm{H}, \mathrm{m}, \mathrm{Ar}-\mathrm{H}), 7.29(2 \mathrm{H}, \mathrm{m}, \mathrm{Ar}-\mathrm{H}), 7.40(2 \mathrm{H}, \mathrm{dt}$, $J=7.7$ and 1.7, $\mathrm{Ar}-\mathrm{H}), 7.66(2 \mathrm{H}, \mathrm{m}, \mathrm{Ar}-\mathrm{H}), 7.67(2 \mathrm{H}, \mathrm{s}$, calix- $\mathrm{OH}), 7.93$ $(2 \mathrm{H}, \mathrm{m}, \mathrm{Ar}-\mathrm{H}), 8.14(2 \mathrm{H}, \mathrm{dd}, J=7.7$ and $1.7, \mathrm{Ar}-\mathrm{H}), 8.62(2 \mathrm{H}, \mathrm{s}, \mathrm{HC}=\mathrm{N})$, $8.66(2 \mathrm{H}, \mathrm{m}, \mathrm{Ar}-\mathrm{H}), 9.24(2 \mathrm{H}, \mathrm{s}, \mathrm{HC}=\mathrm{N}) ; \delta_{\mathrm{C}}\left(75 \mathrm{MHz}, \mathrm{CDCl}_{3}, \mathrm{Me}_{4} \mathrm{Si}\right)$ 31.1, 31.6, 32.0, 33.8, 34.0, 67.2, 73.7, 112.1, 121.2, 122.0, 124.6, 125.1, $125.7,127.7,127.8,132.8,132.9,136.3,141.4,149.7,149.8,150.5,153.5$, $158.2,159.0,160.9$.

\subsubsection{Compound 7}

A solution of dialdehyde calix[4]arene $1(1.0 \mathrm{~g}, 1.05 \mathrm{mmol})$ and diaminomaleonitrile $(0.27 \mathrm{~g}, 2.55 \mathrm{mmol})$ was stirred together in absolute ethanol $(80 \mathrm{~mL})$ and acetic acid $(1 \mathrm{~mL})$ for $24 \mathrm{~h}$. The resulting pale yellow solid was removed by filtration, washed with ethanol and dried in the oven. The solvent of the filtrate was removed under reduced pressure, the residue was taken up in methanol and the insoluble yellow material removed by filtration. The combined yellow materials was analysed as 7 (acetic acid) $\mathbf{1 . 5}$ (1.15 g, 97\%), mp 290-292 ${ }^{\circ} \mathrm{C}$ (decomp.). (Found: C, 71.88; H, 6.49; $\mathrm{N}$, 9.43. $\mathrm{C}_{146} \mathrm{H}_{164} \mathrm{~N}_{16} \mathrm{O}_{18}$ requires: $\left.\mathrm{C}, 72.13 ; \mathrm{H}, 6.80 ; \mathrm{N}, 9.22 \%\right) . \nu_{\max }$ $(\mathrm{KBr}) / \mathrm{cm}^{-1} 3455,3337,2956,2233,2205,1603,1485,1364,1162$, 924, 755; $\delta_{\mathrm{H}}\left(300 \mathrm{MHz}, \mathrm{DMSO}-d_{6}, \mathrm{Me}_{4} \mathrm{Si}\right) 1.15(18 \mathrm{H}, \mathrm{s}, t-\mathrm{Bu}), 1.22$ (18H, s, $t-\mathrm{Bu}$ ), 3.38 (4H, d, $J=12.7, \mathrm{ArCH}_{2} \mathrm{Ar}$ ), 4.25 (4H, d, $J=12.7$, $\left.\mathrm{ArCH} \mathrm{H}_{2} \mathrm{Ar}\right), 4.36\left(8 \mathrm{H}, \mathrm{m}, \mathrm{OCH}_{2} \mathrm{CH}_{2} \mathrm{O}\right), 7.08(4 \mathrm{H}, \mathrm{s}, \mathrm{Ar}-\mathrm{H}), 7.12(2 \mathrm{H}, \mathrm{m}$, $\mathrm{Ar}-\mathrm{H}), 7.13(4 \mathrm{H}, \mathrm{s}, \mathrm{Ar}-\mathrm{H}), 7.20(2 \mathrm{H}, \mathrm{m}, \mathrm{Ar}-\mathrm{H}), 7.61(2 \mathrm{H}, \mathrm{m}, \mathrm{Ar}-\mathrm{H}), 7.74$ $\left(4 \mathrm{H}, \mathrm{s}, \mathrm{NH}_{2}\right), 8.30(2 \mathrm{H}, \mathrm{m}, \mathrm{Ar}-\mathrm{H}), 8.33(2 \mathrm{H}, \mathrm{s}$, calix-OH $), 8.76(2 \mathrm{H}, \mathrm{s}$, $H \mathrm{C}=\mathrm{N}) ; \delta_{\mathrm{C}}\left(75 \mathrm{MHz}, \mathrm{CDCl}_{3}, \mathrm{Me}_{4} \mathrm{Si}\right) 30.8,31.3,31.5,33.5,33.9,67.2$, 73.4, 103.7, 112.4, 113.5, 114.4, 120.8, 123.9, 125.0, 125.6, 126.2, 127.3, 128.0, 133.1, 133.2, 140.9, 146.9, 149.4, 150.0, 150.8, 158.0.

\subsection{X-ray crystallography}

The crystals of $\mathbf{2 a}, \mathbf{2 b}, \mathbf{4}$ and $\mathbf{7}$ were grown from xylene, DMF, DMF and ethyl acetate, respectively, by the method of slow evaporation. Crystallographic data were collected on a Nonius KappaCCD area detector diffractometer using Mo $\mathrm{K} \alpha$ radiation $(\lambda=0.71073 \AA$ ) at a temperature of $150(2) \mathrm{K}$, and all structures were solved by direct methods and refined on all $F^{2}$ data using the SHELXL-97 suite of programs. ${ }^{21}$ Hydrogen atoms not involved in hydrogen bonding were included in idealised positions and refined using the riding model. Absorption corrections were applied on merit.

A number of noteworthy points pertain to the refinements. In particular, the asymmetric unit in 2a contains one molecule of the calix[4]arene, which has trapped one molecule of $m$-xylene. This solvent is disordered, and optimal modelling of this region of the electron density map was achieved by isotropic refinement as two fragments in a 60:40 ratio. The aromatic rings in both xylene fragments were treated as rigid hexagons. C30-C40 also exhibited disorder (55:45 ratio), which was readily modelled. In $\mathbf{2 b}$, the asymmetric units comprises one calix[4]arene molecule and one molecule of DMF, the latter occupying the calix[4]arene pore. Disorder was also evident in this structure, with $\mathrm{C} 70-76$ and 08 being equally disordered over two sites. In addition, the $\beta$-carbons in the $t$-Bu group based on C18 are fragmented over two positions in an $85: 15$ occupancy ratio. One DMF solvent molecule is present in the motif of compound $\mathbf{4}$, while the equivalent motif in $\mathbf{7}$ consists of two derivatised calix[4]arene molecules and three solvent molecules. One tertiary butyl group in each calix[4]arene (based on C7 and C99, respectively) exhibited disorder 65:35 of the methyl groups. These partial carbons were treated isotropically. The ethyl acetate molecule (containing $05 \mathrm{~S}$ and $\mathrm{O6S}$ ) also exhibited disorder in a 65:35 ratio. The larger occupancy fragment was modelled anisotropically, while the minor portion was isotropically treated as non-bonded, fragment atoms approximating to $0.35 \%$ of a molecule. Although the partial hydrogen atoms could not be meaningfully included in the refinement for this latter moiety, they have been included in the unit cell contents. To aid convergence, three distance similarity restraints were applied to $\mathrm{C}-\mathrm{C}, \mathrm{O}-\mathrm{C}$ and $\mathrm{C} \cdots \mathrm{C}$ distance in the solvent. This latter structure was refined using full matrix least squares. Since the number of parameters (1731) for this structure exceeds the SHELXL ${ }^{21}$ array, SHELXH ${ }^{21}$ was used in the final refinement cycles.

Table 2 summarises crystallographic parameters of all four structures. CCDC 692925-692928 contain the supplementary crystallographic data for this paper. This data can be obtained free of charge from the Cambridge Crystallographic Data Centre via www.ccdc.cam.ac.uk/data on request.

\section{Acknowledgements}

The authors would like to thank Dr. J. C. Stephens for useful and helpful discussions. J.M.D.W. would like to thank North Tipperary County Council and the National University of Ireland Maynooth for financial assistance.

\section{References and notes}

1. (a) Ikeda, A.; Shinkai, S. Chem. Rev. 1997, 97, 1713-1734; (b) Weiser, C.; Dieleman, C. B.; Matt, D. Coord. Chem. Rev. 1997, 165, 93-161; (c) Gutsche, C. D. Calixarenes Revisited: Monographs in Supramolecular Chemistry; Royal Society of Chemistry: London, 1998; (d) Mandolini, L.; Ungaro, R. Calixarene in Action; Imperial College: London, 2000; (e) Asfari, Z.; Böhmer, V.; Harrowfield, J.; Vicens, J. Calixarene 2001; Kluwer Academic: Dordrecht, 2001; (f) Beer, P. D.; Hayes, E. J. Coord. Chem. Rev. 2003, 240, 167-189; (g) Redshaw, C. Coord. Chem. Rev. 2003, 244, 4570; (h) Śliwa, W. J. Inclusion Phenom. Macrocyclic Chem. 2005, 52, 13-37.

2. (a) Liang, Z.; Liu, Z.; Gao, Y. Tetrahedron Lett. 2007, 48, 3587-3590; (b) Liang, Z.; Liu, Z.; Gao, Y. Spectrochim. Acta, Part A 2007, 68, 1231-1235; (c) Singh, N.; Kumar, M.; Hundal, G. Tetrahedron 2004, 60, 5393-5405; (d) Liu, Y.; Wang, H.; Wang, L. H.; Li, Z.; Zhang, H.-Y.; Zhang, Q. Tetrahedron 2003, 59, 7967-7972; (e) Pipoosananakaton, B.; Sukwattanasinitt, M.; Jaiboon, N.; Chaichit, N.; Tuntulani, T. Bull. Korean Chem. Soc. 2000, 21, 867-874. 
3. See, for example: (a) Hadjoudis, E.; Mavrids, I. M. Chem. Soc. Rev. 2004, 33, 579588; (b) Vargas, V. C. J. Phys. Chem. A 2004, 108, 281-288; (c) Ohshima, A.; Momotake, A.; Arai, T. J. Photochem. Photobiol. A: Chem. 2004, 162, 473-479; (d) Ogawa, K.; Harada, J.; Fujiwara, T.; Yoshida, S. J. Phys. Chem. A 2001, 105, 34253427.

4. See, for example: (a) Mahajan, R. K.; Kaur, I.; Kumar, M. Sens. Actuators B 2003. 91, 26-31; (b) Tuntulani, T.; Thavornyutikarn, P.; Poompradub, S.; Jaiboon, N.; Ruangpornvisuti, V.; Chaichit, N.; Asfari, Z.; Vicens, J. Tetrahedron 2002, 58 10277-10285; (c) Liu, Y.; Zhao, B.-T.; Zhang, H.-Y.; Wada, T.; Inoue, Y. J. Chem Soc., Perkin Trans. 2 2001, 1219-1223; (d) Pothsree, T.; Seangprasertkij-Magee, R.; Tuntulani, T. J. Inclusion Phenom. Macrocyclic Chem. 1997, 29, 99-107; (e) Seangprasertkij, R.; Asfari, Z.; Arnaud, F.; Vicens, J. J. Org. Chem. 1994, 59, 1741 1744

5. (a) Creaven, B. S.; Deasy, M.; Flood, P. M.; McGinley, J.; Murray, B. A. Inorg. Chem. Commun. 2008, 11, 1215-1220; (b) Bond, A. D.; Creaven, B. S.; Donlon, D. F. Gernon, T. L.; McGinley, J.; Toftlund, H. Eur. J. Inorg. Chem. 2007, 749-756; (c) Creaven, B. S.; Gernon, T. L.; McGinley, J.; Moore, A.-M.; Toftlund, H. Tetrahedron 2006, 62, 9066-9071; (d) Creaven, B. S.; Mahon, M. F.; McGinley, J.; Moore A.-M. Inorg. Chem. Commun. 2006, 9, 231-234; (e) Creaven, B. S.; Gernon, T. L.; McCormac, T.: McGinley, J.; Moore, A.-M.; Toftlund, H. Inorg. Chim. Acta 2005, 358, 2661-2670; (f) Creaven, B. S.; Deasy, M.; Gallagher, J. F.; McGinley, J. Murray, B. A. Tetrahedron 2001, 57, 8883-8887.

6. Creaven, B. S.; Mahon, M. F.; McGinley, J.; Rooney, A. D.; Walsh, J. M. D. Unpublished results.

7. Seangprasertkij, R.; Asfari, Z.; Arnaud, F.; Weiss, J.; Vicens, J. J. Incl. Phenom Macrocyclic Chem. 1992, 14, 141-147.

8. Sousa, C.; Freire, C.; de Castro, B. Molecules 2003, 8, 894-900.

9. Szmant, H. H.; Harmuth, C. H. J. Am. Chem. Soc. 1959, 81, 962-966.

10. Gernon, T. L.; Creaven, B. S.; McGinley, J.; Bond, A. D. Acta Crystallogr. 2006, E62, $\mathrm{m} 1958-\mathrm{m} 1960$

11. See, for example: (a) Albrecht, M.; Burk, S.; Stoffel, R.; Lüchow, A.; Fröhlich, R. Kogej, M.; Schalley, C. A. Eur. J. Inorg. Chem. 2007, 1361-1372; (b) Zhou, X.-P.; Li D.; Zheng, S.-L.; Wu, T. Inorg. Chem. 2006, 45, 7119-7125; (c) Pedrido, R. Romero, M. J.; Bermejo, M. R.; González-Noya, A. M.; Maneiro, M.; Rodríguez, M. J.; Zaragoza, G. Dalton Trans. 2006, 5304-5314.

12. Tuntulani, T.; Poompradub, S.; Thavornyutikarn, P.; Jaiboon, N.; Ruangpornvisuti, V.; Chaichit, N.; Asfari, Z.; Vicens, J. Tetrahedron Lett. 2001, 42, 5541-5544.

13. See, for example: (a) Izzet, G.; Rager, M.-N.; Reinaud, O. Dalton Trans. 2007, 771 780; (b) Dyker, G.; Mastalerz, M.; Müller, I. M. Eur. J. Org. Chem. 2005, 3801-
3812; (c) Soibinet, M.; Déchamps-Olivier, I.; Mohamadou, A.; Aplincourt, M. Inorg. Chem. Commun. 2004, 7, 405-409; (d) Hamdi, A.; Abidi, R.; Ayadi, M. T. Thuéry, P.; Nierlich, M.; Asfari, Z.; Vicens, J. Tetrahedron Lett. 2001, 42, 3595 3598; (e) de Namor, A. F. D.; Piro, O. E.; Salazar, L. E. P.; Aguilar-Cornejo, A. F.; Al-Rawi, N.; Castellano, E. E.; Velarde, F. J. S. J. Chem. Soc., Faraday Trans. 1998, 94, 3097-3104.

14. See, for example: (a) Dorta, R.; Shimon, L. J. W.; Rozenberg, H.; Ben-David, Y.; Milstein, D. Inorg. Chem. 2003, 42, 3160-3167; (b) Zeng, X.; Sun, H.; Chen, L.; Leng, X.; Xu, F.; Li, Q.; He, X.; Zhang, W.; Zhang, Z.-Z. Org. Biomol. Chem. 2003, 1, 1073-1079; (c) Webber, P. R. A.; Cowley, A.; Drew, M. G. B.; Beer, P. D. Chem.-Eur. J. 2003, 9, 2439-2446.

15. See, for example: (a) Ainke, S.; Dong, W.; Nabeshima, T. Inorg. Chem. 2006, 45 , 4677-4684; (b) Costes, J. P.; Lamère, J. F.; Lepetit, C.; Lacroix, P. G.; Dahan, F.; Nakatani, K. Inorg. Chem. 2005, 44, 1973-1982; (c) Dutta, B.; Bag, P.; Adhikary, B.; Flörke, U.; Nag, K. J. Org. Chem 2004, 69, 5419-5427; (d) Gallant, A. J.; Hui, J. K.-H.; Zahariev, F. E.; Wang, Y. A.; MacLachlan, M. J. J. Org. Chem. 2005, 70, 7936-7946.

16. Rojanathanes, R.; Pipoosananakaton, B.; Tuntulani, T.; Bhanthumnavin, W.; Orton, J. B.; Cole, S. J.; Hursthouse, M. B.; Grossel, M. C.; Sukwattanasinitt, M. Tetrahedron 2005, 61, 1317-1324.

17. (a) Gruber, T.; Weber, E.; Seichter, W.; Bombicz, P.; Csöregh, I. Supramol. Chem. 2006, 18, 537-547; (b) Takemura, H.; Iwanaga, T.; Shinmyozu, T. Tetrahedron Lett. 2005, 46, 6687-6690; (c) Pietraszkiewicz, M.; Pietraszkiewicz, O.; Kolodziejski, W.; Wozniak, K.; Feeder, N.; Benevelli, F.; Klinowski, J. J. Phys. Chem. B 2000, 104, 1921-1926.

18. (a) Kim, J.-M.; Min, S. J.; Lee, S. W.; Bok, J. H.; Kim, J. S. Chem. Commun. 2005 3427-3429; (b) Kim, S. K.; Kim, S. H.; Kim, H. J.; Lee, S. H.; Lee, S. W.; Ko, J.; Bartsch, R. A.; Kim, J. S. Inorg. Chem. 2005, 44, 7866-7875.

19. Gale, P. A.; Chen, Z.; Drew, M. G. B.; Heath, J. A.; Beer, P. D. Polyhedron 1998, 17, 405-412.

20. See, for example: (a) Costa, A. I.; Prata, J. V. Supramol. Chem. 2008, 20, 95-108; (b) Sun, X. H.; Chan, C. S.; Wong, M. S.; Wong, W. Y. Tetrahedron 2006, 62, 78467853; (c) Armaroli, N.; Accorsi, G.; Rio, Y.; Ceroni, P.; Vicinelli, V.; Welter, R.; Gu, T.; Saddik, M.; Holler, M.; Nierengarten, J.-F. New J. Chem. 2004, 28, 1627-1637; (d) Gu, T.; Accorsi, G.; Armaroli, N.; Guillon, D.; Nierengarten, J.-F. Tetrahedron Lett. 2001, 42, 2309-2312; (e) Nakamura, R.; Ikeda, A.; Sarson, L. D.; Shinkai, S. Supramol. Chem. 1998, 9, 25-29; (f) Regnouf-de-Vains, J.-B.; Lamartine, R. Tetrahedron Lett. 1996, 37, 6311-6314.

21. Sheldrick, G. M. SHELXL-97; University of Göttingen: Göttingen, Germany, 1996 